J. Lake Sci.(湖泊科学), 2016, 28(5): 944-950

DOI 10. 18307/2016. 0503

(c) 2016 by Journal of Lake Sciences

\title{
水华衰亡过程中微囊藻群体胶鞘结构及其元素组成的变化
}

\author{
施丽梅, 蔡元锋, 孔繁翔**, 于 洋 \\ (中国科学院南京地理与湖泊研究所湖泊与环境国家重点实验室,南京 210008)
}

\begin{abstract}
摘 要: 维系微囊藻群体结构的胶鞘是微囊藻水华维持优势的重要原因之一. 为了探讨微囊藻水华的衰亡机理, 在太湖 梅梁湾水华衰亡过程中 (10 月至次年 1 月), 对微囊藻群体大小的组成做了统计, 同时对单位藻细胞的胶鞘多糖产量变化 进行了检测, 并对微囊藻群体胶鞘的变化进行了能谱扫描电镜观察和元素组成分析. 结果表明, 随着水华的衰亡, 100 $180 \mu \mathrm{m}$ 的微囊藻小群体的比例表现出增多的趋势, 而大于 $180 \mu \mathrm{m}$ 的大群体逐渐减少, 单位藻细胞的多糖含量呈现下降 的趋势. 扫描电镜结果显示了微囊藻群体的胶鞘从完整到逐渐裂解的变化过程, 群体表面的能谱化学元素分析显示, 钠 和磷元素的百分含量呈下降的趋势, 铝和硫元素的百分含量趋于稳定, 而钙和硅元素的百分含量呈上升的趋势. 以上结 果说明了微囊藻群体中单位细胞的多糖产量减少, 群体胶鞘裂解, 元素组成发生变化, 伴随着微囊藻群体的解聚, 出现水 华的衰亡.
\end{abstract}

关键词: 微囊藻; 胶鞘; 扫描电子显微镜/X 射线能谱仪;水华

\section{Changes in structure and element composition of mucilage sheath of Microcystis colony during the bloom decline period}

\section{SHI Limei, CAI Yuanfeng, KONG Fanxiang ${ }^{* *} \&$ YU Yang}

( State Key Laboratory of Lake Science and Environment, Nanjing Institute of Geography and Limnology, Chinese Academy of Sciences, Nanjing 210008, P.R.China)

\begin{abstract}
Mucilage sheath is critical for maintaining predominance of colonial Microcystis in eutrophic freshwaters. To explore mechanism underlying the decline of Microcystis bloom, colony size, polysaccharide content and sheath structure of Microcystis colonies were investigated from October to January when the bloom decline. The results indicated that the proportion of Microcystis with colony size larger than $180 \mu \mathrm{m}$ decreased, while colonies in the 100-180 $\mu \mathrm{m}$ size range increased. Polysaccharide content per cell decreased during the decline period. The scanning electron micrograph showed that sheath structure of Microcystis colonies changed from complete to broken. Element analysis of the surface of Microcystis colonies showed the percentages of Na and $\mathrm{P}$ decreased gradually, $\mathrm{Al}$ and $\mathrm{S}$ fluctuated, while $\mathrm{Ca}$ and $\mathrm{Si}$ increased. These results indicated that changes in polysaccharide content and element composition of colony sheath accompanied with colonial Microcystis disaggregation, and thus led to bloom decline.
\end{abstract}

Keywords: Microcystis; sheath; scan electric microscope/X-ray energy spectrometer; water bloom

微囊藻 (Microcystis spp.) 是一个在全世界广泛分布, 在富营养化的水体中频繁发生水华的蓝藻种类 ${ }^{[1]}$. 在野外条件下,微囊藻大都以群体形式存在. 微囊藻群体主要是以微囊藻分泌的胞外多糖为主要成分的胶 鞘围绕在藻细胞周围形成 ${ }^{[2]}$. 研究表明相比单细胞状态的微囊藻, 群体微囊藻更能耐受低温、黑暗等条 件 ${ }^{[3]}$,并且可以抵御浮游动物的捕食 ${ }^{[4-5]}$. 微囊藻群体胶鞘能够吸收生长所必需的金属元素 ${ }^{[6]}$, 在微囊藻的 漂浮以及群体结构的维持中起到重要的作用 ${ }^{[7]}$. 除此之外, 胶鞘对微囊藻群体的形态和大小有着重要的影 响,而藻细胞表面的多糖在藻细胞聚合形成群体中发挥着重要作用 ${ }^{[8-10]}$.

* 国家自然科学基金项目 (31370509)、江苏省自然科学基金项目 (BK20131466) 和中国博士后基金面上项目 (20090461147) 联合资助.2015-11-20 收稿;2016-01-21 收修改稿. 施丽梅 (1983 ) , 女, 助理研究员; E-mail: lmshi@ niglas.ac.cn.

** 通信作者;E-mail:fxkong@ niglas.ac.cn. 
微囊藻水华在一年中经过衰亡休眠、复苏、生物量增加和上浮积聚 4 个阶段 ${ }^{[11]}$, 其中在秋、冬季节, 微囊 藻水华进人衰亡阶段, 除了小部分微囊藻群体仍然停留在水柱或者下沉到底泥中越冬, 成为来年春季复苏 的主力军 ${ }^{[12]}$, 大部分微囊藻群体消失 ${ }^{[13]}$. 胶鞘多糖是微囊藻在湖泊浮游植物中占据优势的主要原因之一. 水华衰亡期间, 随着温度的逐渐下降, 微囊藻群体胶鞘多糖的分泌可能会受到影响. 已有相关研究表明, 多 糖的合成受到环境条件的影响 ${ }^{[14-17]}$. 然而, 关于微囊藻水华衰亡过程中胶鞘的变化目前研究仍然较少.

为了揭示对维持微囊藻群体优势起关键作用的胶鞘在水华衰亡过程中的变化, 本研究探讨了太湖梅梁 湾水华衰亡过程中的微囊藻群体大小以及单位藻细胞多糖的变化, 并采用能谱扫描电镜 ( SEM-EDS) 方法研 究了微囊藻群体胶鞘和元素组成的变化.

\section{1 材料与方法}

\section{1 微囊藻群体大小组成和单位细胞胶鞘多糖含量的变化}

1.1.1 样品的采集和不同大小群体藻细胞数分析 在微囊藻水华衰亡期间 (10 月至次年 1 月), 在太湖梅梁 湾用 $25^{\#}$ 浮游生物网收集微囊藻群体, 依次用 $180 、 100$ 和 $50 \mu \mathrm{m}$ 尼龙篮绢过滤后, 采用超声波破碎仪, 在 $30 \sim 40 \mathrm{~W}$ 工作功率下, 超声 $1 \mathrm{~min}$, 将群体打散 ${ }^{[18]}$, 采用血球计数板计数每部分的细胞个数, 用来计算组成 不同大小群体的细胞数的比例.

1.1.2 苯酚硫酸法分析单位细胞胶鞘多糖含量的变化 采用苯酚硫酸法分析微囊藻群体胶鞘多糖 ${ }^{[19]}$. 具体 方法是收集一定体积湖水中的微囊藻群体, 浸泡在终浓度为 $3 \%$ 的成二醛中, 在 $4^{\circ} \mathrm{C}$ 进行多糖提取 ${ }^{[20]}$. 以 6000 转/ $\mathrm{min}$ 离心 $10 \mathrm{~min}$ 收集上清液, 采用 3500 道尔顿透析膜透析后用于微囊藻群体胞外多糖浓度的测定. 藻群体沉淀重新悬浮于相同体积的 GF/C 膜滤过的湖水中, 采用 1.1 .1 节中所述的方法打散藻群体计数藻 细胞.

葡萄糖标准曲线的绘制及样品多糖浓度的测定. 准确称取干燥至恒重的无水葡萄糖 $20 \mathrm{mg}$ 于 $500 \mathrm{ml}$ 容 量瓶中, 加水至刻度, 分别吸取 $0.4 、 0.6 、 0.8 、 1.0 、 1.2 、 1.4 、 1.6$ 及 $1.8 \mathrm{ml}$, 用水补至 $2.0 \mathrm{ml}$, 然后加人 $5 \%$ 苯酚 $1 \mathrm{ml}$ 摇匀, 接着垂直加人浓硫酸 $5.0 \mathrm{ml}$, 使浓硫酸迅速冲下去的同时起到混匀的效果, 室温放置 $20 \mathrm{~min}$ 后摇 匀, 在 $490 \mathrm{~nm}$ 处测光密度, $2.0 \mathrm{ml}$ 水按同样的显色操作为空白对照, 横坐标为多糖浓度 $(\mu \mathrm{g} / \mathrm{ml})$, 纵坐标为 光密度值, 得到标准曲线. 取样品液 $1.0 \mathrm{ml}$, 按以上操作步骤测定光密度值, 根据标准曲线公式计算对应多糖 浓度 $(\mathrm{mg} / \mathrm{L})$. 将多糖浓度除以细胞总数可得单位藻细胞的多糖含量.

\section{2 微囊藻群体胶鞘的显微分析}

1.2.1 阿利新兰 (Alcian blue) 染色 用蒸馏水配制 $1 \%$ 的阿利新兰染液, 用稀盐酸分别调节 $\mathrm{pH}$ 值到 2.5 和 0.5 , 在这两种 $\mathrm{pH}$ 值下该染料分别能选择性结合酸性多糖和硫酸多糖而使多糖呈现蓝色 ${ }^{[21]}$, 以此证明两种 多糖的存在. 同时经过染色, 原本无色透明的胶鞘将变得清晰可辨. 吸取两种 $\mathrm{pH}$ 值下该染料各 $1.0 \mathrm{ml}$ 加人 $1.5 \mathrm{ml}$ 离心管中, 加人少量微囊藻群体, 染色 $30 \mathrm{~min}$ 后, 用蒸馏水冲洗微囊藻群体, 直接于光学显微镜下观 察并拍照.

1.2.2 能谱扫描电镜 (SEM-EDS) 分析 微囊藻群体在 $2.5 \%$ 的戊二醛溶液中固定保存直到扫描电镜样品的制 作. 样品的前处理过程如下: 首先用 $0.01 \mathrm{~mol} / \mathrm{L}$ 的磷酸缓冲液将微囊藻群体洗 3 次, 以去除龙二醛. 然后依 次用不同浓度 $(30 \% 、 50 \% 、 70 \% 、 80 \% 、 90 \% 、 100 \%, \mathrm{v} / \mathrm{v})$ 的乙醇溶液进行梯度脱水, 最后在空气中风干. 样品 在喷镀金膜后, 在扫描电镜 ( JSM-5610LV/Vantage IV) 下, 对样品中随机选定的微囊藻群体进行形貌特征观 察并拍照, 同时, 利用与扫描电镜相偶联的 $X$ 射线能谱仪 (实验所用电压为 $15 \mathrm{kV}$ ) 进行微囊藻群体表面元 素组成分析,通过获取二次电子图像得到主要组成元素的相对重量百分比.

\section{2 结果与分析}

\section{1 微囊藻群体大小组成与微囊藻单位细胞胶鞘多糖含量分析}

随着水华的衰亡, 大于 $180 \mu \mathrm{m}$ 的微囊藻群体趋于减少, 50 $100 \mu \mathrm{m}$ 的群体在总群体中所占的比例变化不 大, 而 100 180 $\mu \mathrm{m}$ 的群体显示出增加的趋势 (图 1). 微囊藻群体中大于 $180 \mu \mathrm{m}$ 的比例在 11 月上旬之前出现 增加趋势, 可能是群体体积较小的惠氏微囊藻 (M. wesenbergii) 的比例逐渐减少, 而群体体积较大的铜绿微囊藻 
(M. aeruginosa) 比例增多, 导致总体上大群体的增多;11 月上旬之后, 大于 $180 \mu \mathrm{m}$ 的比例逐渐减少, 有两个方 面的原因:一方面是由于存在不同形态的微囊藻的演替, 如从铜绿微囊藻向水华微囊藻 (M. flos-aquae) 的演 替,一般铜绿微囊藻群体平均大小大于水华微囊藻群体; 另一方面是由于大群体裂解成为小的群体.

葡萄糖的标准曲线为: $y=0.007 x-0.016, R^{2}=0.99$, 据此公式得出: 在微囊藻水华衰亡过程中的微囊藻群 体中, 单位细胞产生的胞外多糖含量总体呈现先增加后减少的趋势, 从 $8.9 \pm 0.6 \mathrm{pg} / \mathrm{cell}$ 增加到 $25.8 \pm 1.8 \mathrm{pg} /$ cell, 然后下降到 $3.4 \pm 0.3 \mathrm{pg} / \operatorname{cell}$ ( 图 2). 在 11 月上旬之前, 多糖含量的增加与大于 $180 \mu \mathrm{m}$ 的藻群体的增加 一致, 可能与微囊藻不同种类的演替有关, 而在 11 月之后, 单位细胞产生的胞外多糖含量的下降, 与多糖合 成受到环境因素如温度、光照以及不同微囊藻种属的影响有关 ${ }^{[22]}$. 值得注意的是本文针对的是微囊藻群体 的附着多糖, 即微囊藻群体胶鞘中的主要组分, 在微囊藻形成群体上发挥着重要作用 ${ }^{[10]}$. 多糖产量减少会 影响群体大小 ${ }^{[23]}$, 引起胶鞘发生变化.

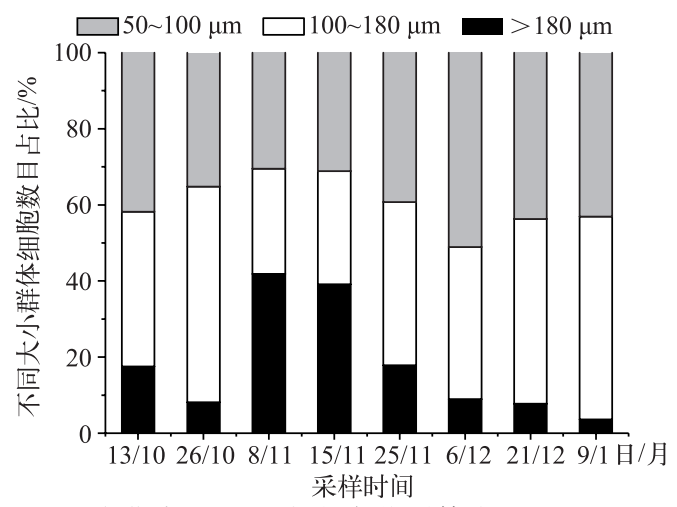

图 1 水华衰亡过程中微囊藻群体大小组成变化

Fig. 1 Changes in size fractionated Microcystis colonies during the bloom decline period

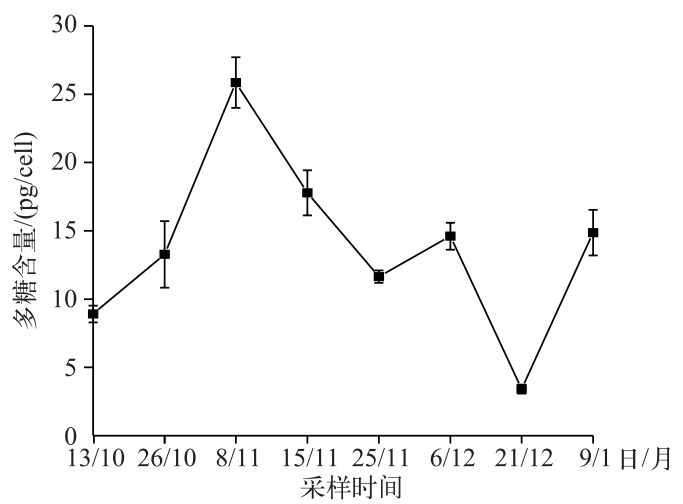

图 2 水华衰亡过程中单位微囊藻细胞多糖含量的变化

Fig. 2 Changes in polysaccharide content of Microcystis colonies during the bloom decline period

\section{2 微囊藻群体的阿利新兰染色}

微囊藻群体经过阿利新兰染色, 胶鞘结构明显, 围绕在微囊藻细胞周围, $\mathrm{pH}$ 值为 0.5 (图 3A) 和 2.5(图
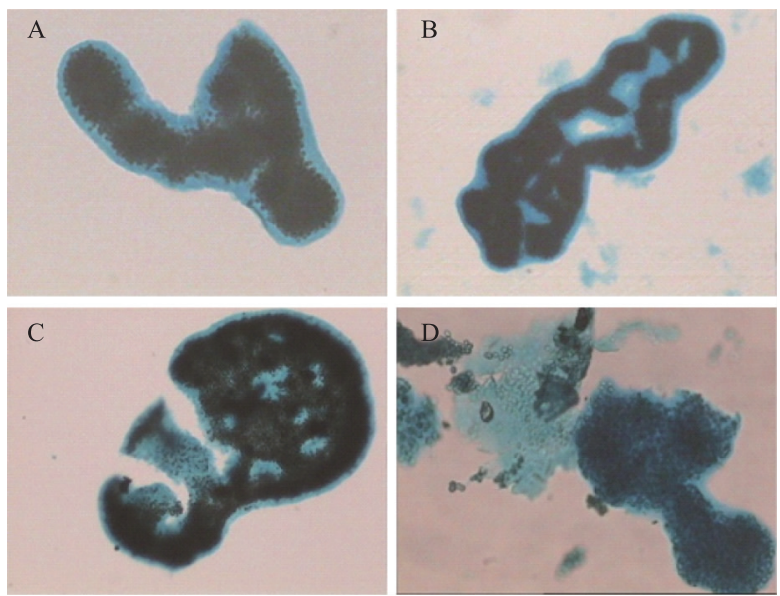

图 3 微囊藻群体的阿利新兰染色结果: (A) $\mathrm{pH}$ 值为 0.5 时所染色的微囊藻群体; (B) $\mathrm{pH}$ 值为 2.5 时所 染色的微囊藻群体; ( C) 正在裂解的微囊藻群体 ( $\mathrm{pH}$ 值为 2.5 ); ( D) 破碎的微囊藻群体 ( $\mathrm{pH}$ 值为 2.5)

Fig.3 Microcystis colonies stained with alcian blue: (A) colony stained at pH 0.5 ; ( B) colony stained at

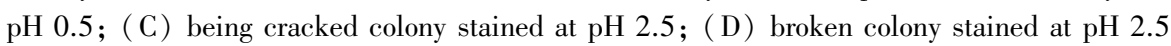


3B) 都可将微囊藻群体染色, 显示群体中含有酸性多糖和硫酸多糖, 这与以往报道的结果相似 ${ }^{[1,24-25]}$. 在正 在裂解和已经破碎的微囊藻群体中 (图 3C、D), 可以看到微囊藻群体胶鞘的开裂, 破碎的藻群体中含较少细 胞的胶鞘碎片, 说明了微囊澡群体的裂解以及藻细胞的脱落.

\section{3 水华衰亡过程中微囊藻胶鞘结构以及元素组成变化}

扫描电镜分析结果显示, 不同时间的微囊藻群体胶鞘形态明显不同. 在 10 月、11月 8 日和 11 月 15 日 采集的微囊藻群体具有较完整的胶鞘结构, 细胞结合紧密, 并包裹在胶鞘中 (图 4A、B、C、D), 说明此时的微 囊藻群体还没有开始衰亡. 而在后面的几个时期即 11 月 25 日、12 月以及 1 月所采集的微囊藻群体,胶鞘结 构趋于破碎, 质地变硬, 胶鞘出现裂解, 胶鞘内的细胞外翻, 细胞分散地裸露在胶鞘的表面 (图 4E、F、G、H), 一些藻细胞从群体中脱落出去, 表现为采回来的微囊藻群体很容易解散. 这说明随着水华的衰亡, 维持微囊 藻群体结构的胶鞘逐渐老化, 藻细胞脱落, 使得部分微囊藻不能维持群体的状态, 从而被浮游动物捕食, 或 者因为没有胶鞘的保护而无法耐受低温环境而死亡, 因为单细胞的微囊藻对低温和黑暗的耐受都低于群体 状态的微囊藻 ${ }^{[3]}$, 从而导致微囊藻水华的衰亡.
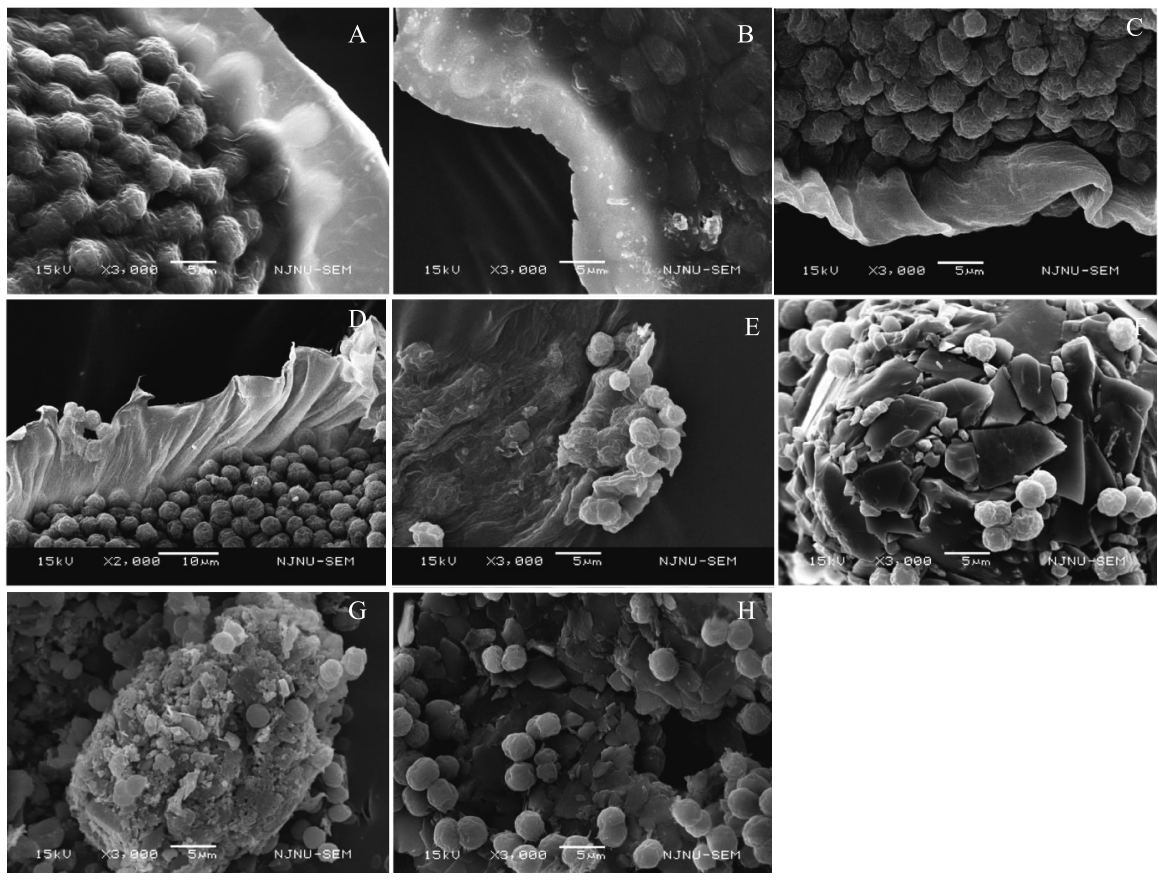

图 4 水华衰亡过程中微囊藻群体胶鞘的扫描电镜照片: A、B、C、D、E、F、G 和 H 分别是

10 月 13 日、 10 月 26 日、 11 月 8 日、 11 月 15 日、 11 月 25 日、 12 月 6 日、 12 月 21 日和 1 月 9 日所 采集的微囊藻群体 (图中的电镜扫描照片代表该时期大部分微囊藻的群体状态)

Fig.4 Scanning electron micrographs of Microcystis colonies during the bloom decline period:

A, B, C, D, E, F, G and H showed samples on 13 October, 26 October, 8 November, 15 November, 25 November, 6 December, 21 December and 9 January, respectively

元素组分分析结果显示 (图 5), 除了高含量的碳和氧元素(两者含量相对稳定,在主要组成元素中分别 占 $60 \%$ 和 30\%左右, 图 5A), 以及部分群体中有含量较低的钾 $(\mathrm{K}) 、$ 、镁 $(\mathrm{Mg}) 、$ 、铁 $(\mathrm{Fe})$ 以及氯 $(\mathrm{Cl})$ 元素 (图 $5 \mathrm{D})$ 之外, 主要的元素有钙 $(\mathrm{Ca}) 、$ 硅 $(\mathrm{Si})$ 、钠 $(\mathrm{Na})$ 、铝 $(\mathrm{Al})$ 、磷 $(\mathrm{P})$ 和硫 $(\mathrm{S})$ ( 图 5B、C), 其中含量最高的是 $\mathrm{Na} 、 \mathrm{P} 、 \mathrm{Ca}$ 和 $\mathrm{Si}$ 元素, 这几种元素的相对重量百分比在水华衰亡过程的微囊藻群体中发生了变化. 其中 $\mathrm{Ca}$ 和 $\mathrm{Si}$ 元素在几个主要的元素组分中的比例呈增加趋势, $\mathrm{Na}$ 和 $\mathrm{P}$ 元素所占的比例则呈现波动下降的趋势, $\mathrm{Al}$ 和 $\mathrm{S}$ 元素则围绕初始值上下浮动. 
微囊藻的胶鞘具有吸附微量元素的作用, 能够供给藻细胞生长必须的元素 ${ }^{[26]}$. 胶鞘的吸附功能实际上 是源于其主要组分多糖对于金属元素的吸附, 吸附的机理包含络合、离子交换和表面沉降等, 吸附能力与环 境温度, $\mathrm{pH}$ 值, 离子强度、形态和种类有关, 但主要还是取决于多糖本身结构和功能基团如羧基、羟基、磷酸 基等 ${ }^{[27]}$. 因此, 胶鞘表面元素含量的变化在一定程度上反映了胶鞘多糖对元素吸附功能的变化. 因而对于 了解微囊藻群体所处的状态有重要的参考作用. 在所检测到的主要元素中, 碳和氧含量很高, 说明了所检测 的颗粒物质来自于胶鞘, 而非非生物杂质颗粒. 除此之外, 含量比较高的元素有 $\mathrm{Na} 、 \mathrm{P} 、 \mathrm{Ca}$ 和 $\mathrm{Si}$. 其中 $\mathrm{Na} 、 \mathrm{P}$ 元素是藻生长必需的元素之一, 能够影响藻的大多数代谢活动, 尤其是光合作用 ${ }^{[2829]}$. $\mathrm{Si}$ 元素存在于微囊藻 群体中已有相关报道 ${ }^{\left[{ }^{[0]}\right.}$, 但是其作用机制并不清晰. 微囊藻胶鞘多糖中所含有的酸性多糖能够高效地螯合 金属离子, 尤其是 $\mathrm{Ca}$ 离子 ${ }^{[31]}$, 而 $\mathrm{Ca}$ 的浓度会影响到微囊藻多糖产量和群体大小 ${ }^{[32]}$. 也有研究报道蓝藻表 面含有较高含量的 $\mathrm{Ca}$ 和 $\mathrm{Si}$ 元素, 可以导致蓝藻的钲化和硅化 ${ }^{[33-34]}$. 我们推测在温度逐渐降低的过程中, 微 囊藻细胞产生胞外多糖含量减少, 而胶鞘吸附的钻和硅元素相对增多, 伴随着胶鞘的质地变硬、变脆、易于 裂解, 从而导致了水华的衰亡.
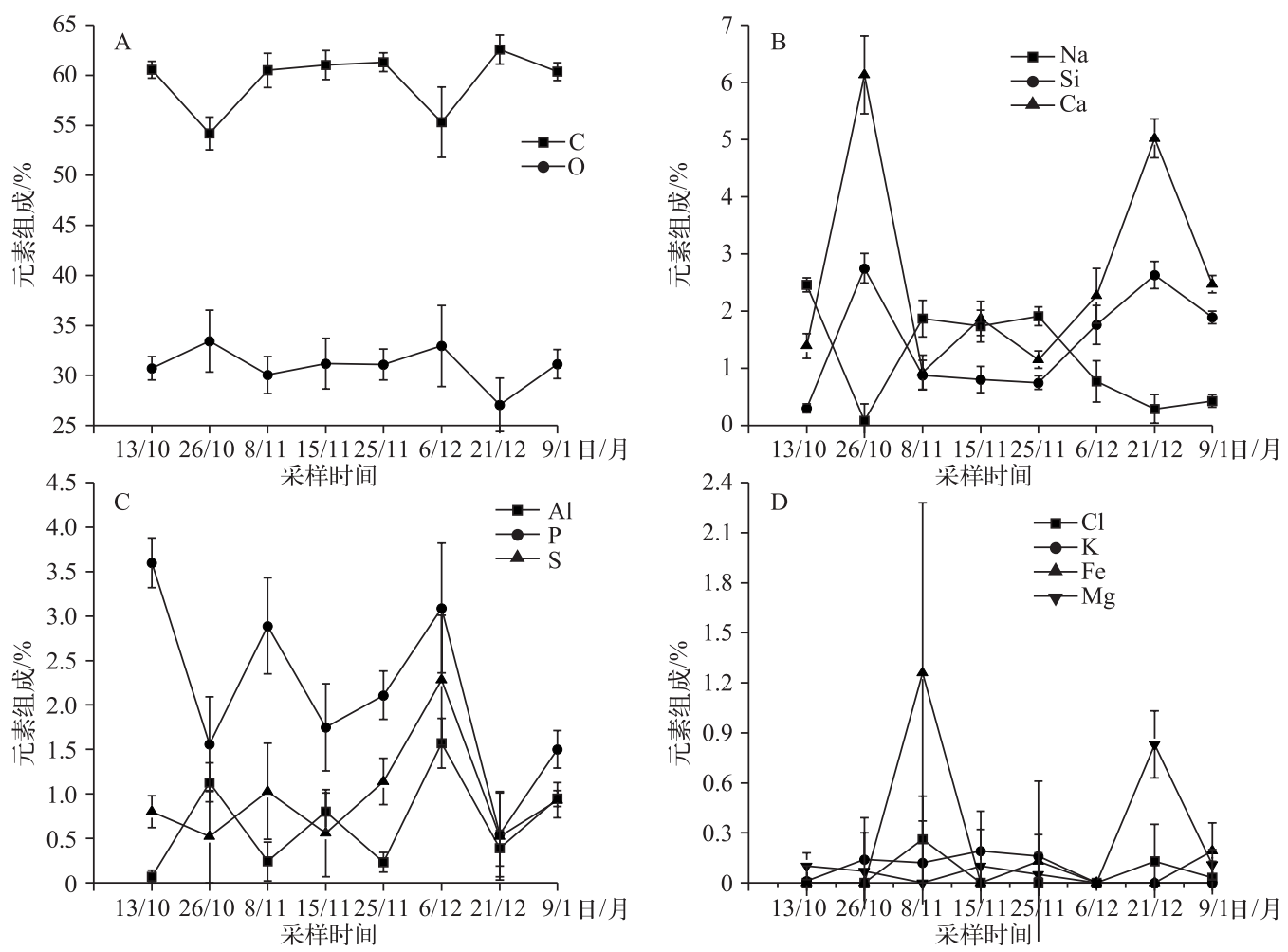

图 5 微囊藻群体胶鞘主要元素组成

Fig.5 Elements composition in sheath of Microcystis colonies determined by SEM-EDS

\section{3 结论}

在富营养化水体中, 每年秋、冬季节微囊藻水华开始衰亡, 然而衰亡的机制并不清楚. 微囊藻维持优势 的一个重要原因是其具有胶鞘, 形成群体. 因此, 本文对太湖梅梁湾微囊藻水华衰亡过程中微囊藻群体的胶 鞘结构变化进行了分析. 结果表明: 随着蓝藻水华的衰亡, 大于 $180 \mu \mathrm{m}$ 的微囊藻群体趋于减少, 而 $100 \sim 180$ $\mu \mathrm{m}$ 的群体显示出增加的趋势; 单位细胞产生的胞外多糖含量呈下降的趋势; 胶鞘结构趋于破碎, 质地变硬, 胶鞘出现裂解, 胶鞘内的细胞外翻, 一些藻细胞从群体中脱落出去, 表现为采回来的微囊藻群体很容易解散. 胶鞘中的 $\mathrm{Na}$ 和 $\mathrm{P}$ 元素所占的比例则呈现波动下降, $\mathrm{Ca}$ 和 $\mathrm{Si}$ 元素的比例呈增加的趋势. 


\section{4 参考文献}

[ 1 ] Sun Huiqun, Zhu Lin, Gao Wenbao. Analysis of the causes for Microcystis bloom in freshwater lakes. Bulletin of Biology, 2005, 40 (8) : 23-24 (in Chinese with English abstract). [孙慧群, 朱琳, 高文宝. 淡水湖泊中微囊藻水华的成因分 析. 生物学通报, 2005, 40(8): 23-24.]

[ 2 ] Reynolds CS, Jaworski GHM, Cmiech HA et al. On the annual cycle of the blue-green alga Microcystis aeruginosa Kutz Emend Elenkin. Proceedings of the Royal Society of London Series B-Biological Sciences, 1981, 293: 419-477.

[ 3 ] Wu Z, Song L, Li R. Different tolerances and responses to low temperature and darkness between waterbloom forming cyanobacterium Microcystis and a green alga Scenedesmus. Hydrobiologia, 2008, 596: 47-55.

[ 4 ] Yang Z, Kong F, Shi X et al. Changes in the morphology and polysaccharide content of Microcystis aeruginosa (cyanobacteria) during flagellate grazing. Journal of Phycology, 2008, 44: 716-720.

[ 5 ] Yang Z, Kong F. Formation of large colonies: a defense mechanism of Microcystis aeruginosa under continuous grazing pressure by flagellate Ochromonas sp. Journal of Limnology, 2012, 71: 61-66.

[ 6 ] Parker DL, Schram B, Plude JL et al. Effect of metal cations on the viscosity of a pectin-like capsular polysaccharide from the cyanobacterium Microcystis flosaquae C3-40. Applied and Environmental Microbiology, 1996, 62: 1208-1213.

[ 7 ] Brookes JD, Ganf GG. Variations in the buoyancy response of Microcystis aeruginosa to nitrogen, phosphorus and light. Journal of Plankton Research, 2001, 32: 399-411.

[ 8 ] Xu H, Jiang H, Yu G et al. Towards understanding the role of extracellular polymeric substances in cyanobacterial Microcystis aggregation and mucilaginous bloom formation. Chemosphere, 2014, 117: 815-822.

[ 9 ] Myklestad S. Release of extracellular products by phytoplankton with special emphasis on polysaccharides. Science of the Total Environment, 1995, 165: 155-164.

[ 10] De Philippis R, Sili C, Vincenzini M. Response of an exopolysaccharide-producing heterocystous cyanobacterium to changes in metabolic carbon flux. Journal of Applied Phycology, 1996, 8: 275-281.

[11] Kong Fanxiang, Gao Guang. Hypothesis on cyanobacteria bloom-forming mechanism in large shallow eutrophic lakes. Acta Ecologica Sinica, 2005, 25(3) : 589-595 (in Chinese with English abstract). [孔繁翔, 高光. 大型浅水富营养化湖泊 中蓝藻水华形成机理的思考. 生态学报, 2005, 25(3): 589-595.]

[12] Verspagen JMH, Snelder EOFM, Visser PM et al. Benthic-pelagic coupling in the population dynamics of the harmful cyanobacterium Microcystis. Freshwater Biology, 2005, 50: 854-867.

[13] Havens KE ed. Cyanobacteria blooms: effects on aquatic ecosystems. In: Hudnell HK ed. Cyanobacterial harmful algal blooms: State of the science and research needs. New York: Springer, 2008, 619: 733-748.

[14] Pereira S, Zille A, Micheletti E et al. Complexity of cyanobacterial exopolysaccharides: composition, structures, inducing factors and putative genes involved in their biosynthesis and assembly. FEMS Microbiology Reviews, 2009, 33: 917-941.

[15] Xiao Yan, Gan Nanqin, Zheng Lingling et al. Studies on morphological responses to light in colonial Microcystis and the underlying physiological mechanisms. Acta Hydrobiologica Sinica, 2014, 38: 35-42 (in Chinese with English abstract). [肖艳, 甘南琴, 郑凌凌等. 光强对微囊藻群体形态的影响及其生理机制研究. 水生生物学报, 2014, 38: 35-42.]

[16] Yang Z, Geng LL, Wang W et al. Combined effects of temperature, light intensity, and nitrogen concentration on the growth and polysaccharide content of Microcystis aeruginosa in batch culture. Biochemical Systematics and Ecology, 2012, 41: 130-135.

[17] Ma J, Brookes JD, Qin B et al. Environmental factors controlling colony formation in blooms of the cyanobacteria Microcystis spp. in Lake Taihu, China. Harmful Algae, 2014, 31:136-142.

[18] Reynolds CS, Jaworski GHM. Enumeration of natural Microcystis populations. British Phycological Journal, 1978, 13: 269-277.

[19] Cai Yuanfeng, Shi Limei, Li Pengfu et al. Composition of bacterial community related to degrading the exopolysaccharide from the cyanobacterium Microcystis aeruginosa. J Lake Sci, 2009, 21(3) : 369-374 (in Chinese with English abstract). DOI: $10.18307 / 2009.0309$. [ 蔡元锋, 施丽梅, 李朋富等. 与微囊藻胞外多糖降解相关的微生物菌群分析. 湖泊科 学, 2009, 21(3): 369-374.]

[20] Li P, Cai Y, Shi L et al. Microbial degradation and preliminary chemical characterization of Microcystis exopolysaccharides 
from a cyanobacterial water bloom of Lake Taihu. International Review of Hydrobiology, 2009, 94: 645-655.

[21] Crayron MA. A comparative cytochemical study of volvocacean matrix polysaccharides. Journal of Phycology, 1982, 18: 336-344.

[22] Xu F, Zhu W, Xiao M et al. Interspecific variation in extracellular polysaccharide content and colony formation of Microcystis spp. cultured under different light intensities and temperatures. Journal of Applied Phycology, 2015, 90(1): 1-9. DOI : 10.1007/s10811-015-0707-1.

[23] Zhu W, Dai X, Li M. Relationship between extracellular polysaccharide (EPS) content and colony size of Microcystis is colonial morphology dependent. Biochemical Systematics and Ecology, 2014, 55: 346-350.

[24] Mei Qiuhong, Miao Yueqiu, Zhang Chengwu et al. Preliminary studies on the isolation, purification, and physicochemical properties of extracellular acidic polysaccharide from Microcystis aeruginosa var. major. J Lake Sci, 2005, 17(4) : 322-326 (in Chinese with English abstract). DOI: 10.18307/2005.0407. [ 梅秋红, 缪月秋, 张成武等. 铜绿微囊藻 (Microcystis aeruginosa var. major) 胞外酸性多糖的分离、纯化及其理化特性. 湖泊科学, 2005, 17(4) : 322-326.]

[25] Wang Xida, Wu Guorong, Chen Jingyao et al. Separation, purification, and structural characterization of acidic polysaccharide from Microcystis aeruginosa. Journal of Chinese Medicinal Materials, 2003, 26(12): 865-867 (in Chinese with English abstract). [王习达, 吴国荣, 陈景耀等. 铜绿微囊藻酸性多糖的分离、纯化与结构研究. 中药材, 2003,26 (12) : 865-867.]

[26] Parker DL, Rai LC, Mallick N et al. Effects of cellular metabolism and viability on metal ion accumulation by cultured biomass from a bloom of the cyanobacterium Mycrocistis aeruginosa. Applied and Environmental Microbiology, 1998, 64: 1545-1547.

[27] Li WW, Yu HQ. Insight into the roles of microbial extracellular polymer substances in metal biosorption. Bioresource Technology, 2014, 160: 15-23.

[28] Wetzel RG. Limnology. Lake and river ecosystems: third edition. London: Academic Press, 2001.

[29] Miller AG, Turpin DH, Canvin DT. Na+ requirement for growth, photosynthesis and pH regulation in Alkalotolerant cyanobacterium Synechococcus leopoliensis. Journal of Bacteriology, 1984, 159: 100-106.

[30] Sigee DC, Levado E. Cell surface elemental composition of Microcystis aeruginosa: high-Si and low-Si subpopulations within the water column of a eutrophic lake. Journal of Plankton Research, 2000, 22 : 2137-2153.

[31] Decho AW. Molecular-scale events influencing the macroscale cohesiveness of exopolymers. In: Krumbein WE, Paterson DM, Stal LJ eds. Biostabilization of Sediments. BIS, Oldenburg, Germany, 1994: 135-148.

[32] Wang YW, Zhao J, Li JH et al. Effects of calcium levels on colonial aggregation and buoyancy of Microcystis aeruginosa. Current Microbiology, 2011, 62: 679-683.

[33] Merz-Preiß M, Riding R. Cyanobacterial tufa calcification in two freshwater streams: ambient environment, chemical thresholds and biological processes. Sedimentary Geology, 1999, 126: 103-124.

[34] Likhoshway EV, Sorokovikova EG, Bel' kova NL et al. Silicon mineralization in the culture of cyanobacteria from hot springs. Doklady Biological Sciences, 2006, 407: 201-205. 